\title{
Equity finance: matching liability to power
}

\author{
By C.A.E. Goodhart and R.M. Lastra*
}

\section{Introduction}

In his regular Monday morning column in The Daily Telegraph, (4 June 2018), the economist, Roger Bootle wrote,

"Market failure applies most notably with regard to executive pay. In practice, senior pay awards are decided by a cosy cabal, reminiscent of the worst of trade union excesses. ${ }^{1}$ It isn't usually the level of pay that infuriates people. It is rather the often sketchy relationship between pay and performance and, especially, the lack of appropriate downsides in the event of individual or corporate failure. This is the very opposite of capitalism in the raw, which depends as much upon the purging effect of failure as the incentivising effect of success."

The basic problem is that CEOs, and other senior managers, are largely remunerated in ways that depend on the level of equity prices, also known as the bonus culture, and equity holders have limited liability. With unlimited upside potential, but limited downside, this puts an equity holder into the position of having a call option on the residual assets of the enterprise. The value of such options increases with risk. This is because when the downside risk occurs, those with limited liability can shift the risk onto the other creditors, depositors, bond holders, trade creditors and taxpayers.

In simple terms equity holders with limited liability are insured against the risk of really bad outcomes. When such (tail) risk occurs, such equity holders can shift the costs arising onto others, e.g. employees, creditors of various kinds and, in the last resort, taxpayers.

The limited liability of equity holders is, we contend, by far the biggest source of moral hazard and risk shifting in a capitalist economy. Yet the 'moral hazard fundamentalists', to use Tim Geithner's phrase, have tended to focus on less central features of our system, such as deposit insurance, mutual fiscal support and other forms of insurance against adversity. Has there been some (unconscious?) bias in the identification of 'moral hazard'?

A consequence of limited liability for shareholders is that the return on their investment, as a function of the profitability of the firm in which they have an equity share, is flat when the company is doing badly or becomes insolvent, but is strongly upwards sloping when the public company is doing well. This is shown graphically in Figure 1 below.

\footnotetext{
* Charles Goodhart is Emeritus Professor at the London School of Economics. Rosa Lastra is the Sir John Lubbock Chair of Banking Law at the Centre for Commercial Law Studies, Queen Mary University of London. E-mail: r.lastra@qmul.ac.uk

We would like to acknowledge with gratitude the excellent and extensive research assistance provided by Alan Brener together with helpful contributions by Guy Morton, Alexander Hoare, Susan Rice, Steven Schwarcz, Simon Gleeson, Katrien Morbee, Marke Raines, Amy and Bert Westbrook, Joseph Gitau Mburu and Luc Thévenoz.

1 Also see inter alia Deborah Hargreaves, 'Are chief executives overpaid?', (Cambridge, UK: Polity Press), (2018).
} 
Figure 1

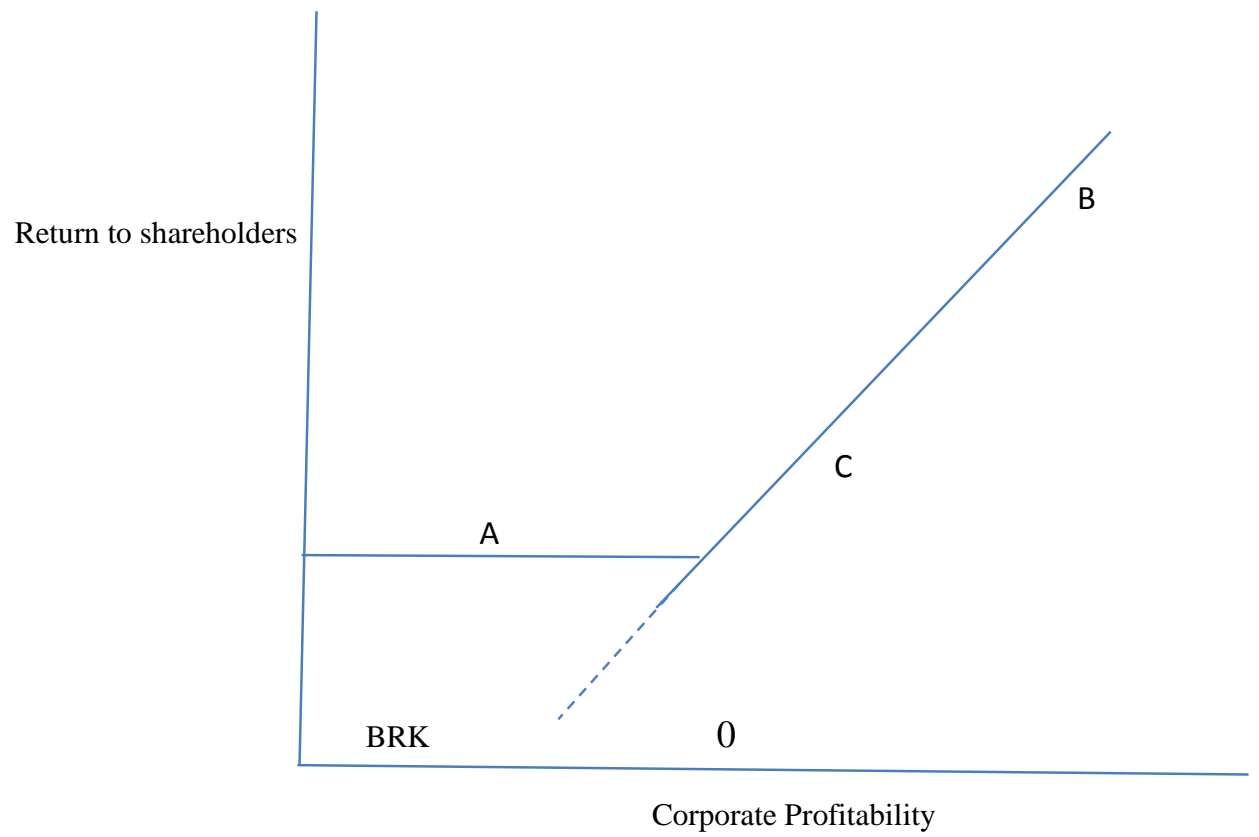

BRK: Point of Corporate Bankruptcy

With a return structure of this kind, the shareholders are led to prefer a riskier strategy, as shown in the figure, with an even chance of an outcome of A and B, rather than a completely safe policy, as shown in the diagram at point $\mathrm{C}$. So, shareholders have an innate preference to encourage management to take on riskier activities. Such shareholder preference for risk is somewhat abated by loss aversion, see for example Kahneman (2012). ${ }^{2}$ But that, in turn, is reduced by appropriate diversification, so that the loss involved on any single portfolio holding is limited. ${ }^{3}$ So, the implication is that limited liability naturally leads shareholders to push management to adopt riskier strategies than would be socially optimal.

In earlier years the pressure on management was mitigated by the fact that managers were primarily paid by a cash salary unrelated to equity valuation. Moreover, other considerations, such as reputation and pride in developing a successful company over the long term, had the effect of constraining managers willingness to take on risk. But, one of the other possible incentives on managerial behaviour, as a result, was to spend resources on activities that might bolster managerial reputation and personal comfort, rather than maximising profits. Such considerations involved size and spending money on managerial perks, including not only such perks as company planes and

2 D. Kahneman, Thinking, Fast and Slow, (London: UK: Penguin Books), (2012). Part IV on Choices, pp 269376, focusses on loss aversion.

${ }^{3}$ The paper by John Armour and Jeffrey Gordon, 'Systemic harms and shareholder value' (The Journal of Legal Analysis, Volume 6, Issue 1, 2014 https://academic.oup.com/jla/article/6/1/35/933345) argues that - with respect to systemic risk at least - diversified shareholders do care, as the systemic spillovers - to a limited extent - will produce losses throughout their diversified portfolio. 
chauffeur driven cars, but also fancy, prestigious architecture, head offices, etc. The cry went up, as a result, that managerial incentives should become better aligned with the interests of shareholders, possibly one of the worst ideas developed by academic economists in recent decades!

Partly in response to public attitudes then, about soaring managerial pay and perks, President Clinton introduced measures in 1993,

"when he effectively set a $\$ 1$ million limit on directors' pay by making anything above that level non-tax deductible for companies. However, in the small print of his legislation, was a clause that specified payments with performance conditions were exempt from the $\$ 1$ million rule. That effectively meant company boards boosted all salaries to $\$ 1$ million and paid bonuses and extras in stock options that directors could cash in for shares at a later date. This prompted an explosion in executive awards...", Hargreaves, op cit., page 77.

The result of such alignment of managerial incentives with those of shareholders, in some large part consciously done, resulted in there being the exact same incentive on management to give priority to policies that would maximise equity valuation; naturally this would generally lead them to pursue additional risk. Moreover, the expected lifetime incumbency of most CEOs is relatively short, five years or less, and that means that the incentive on them is to maximise short-term equity valuations. ${ }^{4}$ This can most easily be achieved by accepting a riskier financial structure, e.g. buybacks to increase leverage and raise RoE, reducing the headcount of employment, and cutting out such longer-term investment, notably in $\mathrm{R} \& \mathrm{D}$, whose return was unlikely to become clear for a long time. ${ }^{5}$

While the moral hazard inherent in limited liability equity usage has currently slipped under the radar, ${ }^{6}$ this was decidedly not so in the $18^{\text {th }}$ and $19^{\text {th }}$ centuries, as recorded in Section II. From the South Sea Bubble onwards, the moral hazard dangers of limited liability equity financing was prominent in the minds of all concerned in the Victorian era, investors, entrepreneurs and the authorities. In Section II of this paper, we document the historical record of using unlimited liability, and then double liability in the case of national banks in the USA, with also reference to a few instances of applying particular liability requirements to specific classes of equity holders.

The basic reason why unlimited, or multiple, liability requirements for equity holders became progressively abandoned during the latter part of the $19^{\text {th }}$ and first half of the $20^{\text {th }}$ century was that these required that such equity holders had both wealth (to meet such potential liability), knowledge about other equity holders and the enterprise, and sufficient power to prevent the enterprise becoming

\footnotetext{
${ }^{4}$ Lucian Bebchuk, Alma Cohen and Holger Spamann in 'The Wages of Failure: Executive Compensation at Bear Stearns and Lehman 2000-2008', Yale Journal on Regulation, Vol. 27, Issue 2, 2010, show that managers were able to cash in a lot of the profits before the collapse. Bebchuk and Spamann in "Regulating Bankers' Pay" (2009). Harvard Law School John M. Olin Center for Law, Economics and Business Discussion Paper Series. Paper 634 (the Georgetown Law Journal, Vol. 98:247) deal with the the moral hazard inherent in bankers' pay.

Michael Jensen and William Meckling in "Theory of the Firm: Managerial Behaviour, Agency Costs and Ownership Structure”, Journal of Financial Economics 3 (1976), 305-360, dealt with the distinction between pecuniary and non-pecuniary benefits.

5 There is a counter-argument pointing to the high stock market valuations of tech companies which during their early lives can be expected to pay out nothing; with the implication that this shows that shareholders and management do give proper full valuation to longer-term future returns. But the prospects for such companies are inherently risky, and it is the lure of potentially massive future returns, with an offsetting significant probability of total collapse, that attracts investors, rather than the long-term nature of their activities per se. 6 Though see Schwarcz, "The Governance Structure of Shadow Banking: Rethinking Assumptions About Limited Liability,” 90 Notre Dame Law Review 1 (2014), also available at http://ssrn.com/abstract=2364126.
} 
unduly risky. In other words, in an unlimited liability world, equity holders had to be predominantly 'insiders'; equities then were just too risky for 'outsiders' to hold.

What then happened towards the end of the $19^{\text {th }}$ century was that the scale of the efficient enterprise, e.g. steel production, chemicals, railways, banks, etc., etc., became sufficiently large that the required equity base (if the enterprise was not to become too excessively leveraged) became too large for insiders, e.g. family and friends, to finance on their own. Equity finance now had to be provided by the much larger mass of outsiders, who had neither the power to control the working of the enterprise, nor detailed information, nor often the wealth to face unlimited, or even multiple, liability. As set out in more detail in Section II, there was a tendency in the US during the 1920s to encourage a wider range of (outsider) shareholding. When the Depression hit in the early 1930s, attempts to call on the additional liability of such outside shareholders proved to have high transaction costs, together with generating considerable political opposition. The result was a general acceptance of limited liability for all, which has continued until today.

As The Economist wrote in 1926:-

The economic historian of the future may assign to the nameless inventor of the principle of limited liability, as applied to trading corporations, a place of honor with Watt and Stephenson, and other pioneers of the Industrial Revolution. The genius of these men produced the means by which man's command of natural resources was multiplied many times over; the limited liability company, the means by which huge aggregations of capital required to give effect to their discoveries were collected, organized, and efficiently administered.

\section{The Economist, 18 December 1926}

Nevertheless, the criticism of limited liability companies has several facets; it is argued that it leads to managers assuming excessive risk, being overpaid, and failing to undertake sufficient long-term investment, especially R\&D.7 The first two criticisms, excessive risk and excessive pay, were particularly levied at banks and other financial intermediaries in the aftermath of the Great Financial Crisis (GFC). There have been a variety of proposals aimed at checking or preventing such malfunctions. One set of such proposals has focussed on limiting the business structures of banks and other financial intermediaries. Examples of such proposals include narrow banking in various guises, ringfencing of core retail financial structures, and a variety of other regulatory measures. A recent addition to this set is by Conti-Brown, arguing for the abolition of limited liability for Systemically Important Financial Institutions (SIFIs), unless they become very highly capitalised.

\footnotetext{
7 In a recent article entitled 'Rethink the purpose of the corporation' (Financial Times, 12 December 2018), Martin Wolf criticises the mantra of shareholder value maximization affirming that in the cases of highly leveraged banking the Anglo American model of corporate governance does not work. He refers to a number of books - including Colin Mayer's 2018 Prosperity - that suggest that capitalism is substantially broken. In a similar vein, John Plender in "Shareholders dethroned as rulers of value" (Financial Times, 3 January 2019), criticises the exisiting corportate governance model of shareholder primacy and advocates the redefinition of directors' legal duties to other stakeholders, following investors' greater emphasis on environmental and social factors in corporate performance, while Andrew Edgecliffe-Johnson in "Beyond the bottom line" (Financial Times, 5/6 January 2019) also questions the doctrine of shareholder primacy and quoting Colin Mayer's Prosperity suggests a broader social purpose, arguing that non-shareholders are ready to try something different.
} 
Another set of responses, aimed more widely at the general governance structure of (public) corporations, has considered such remedies as two-tier governing boards, à la German system, and changing the statutory duty of governing boards, for example as argued by Schwarcz.

A third, and final, set of proposals would adjust the link aligning the interests of shareholders and managers, by imposing additional duties on managers, either through tougher legal requirements, (see Kokkinis, 2018 $)^{8}$ or by changing the incentive and remuneration terms for management. We further discuss the proposals by Conti-Brown, Schwarcz and Kokkinis in Section III. Several of these alternative proposals have involved extending the ambit of the law, either criminal or civil, to cover managerial failings and excessive risk taking. But taking risks, unless spectacularly egregious, is not illegal. Moreover, all too often the managers who have led firms down the garden path to failure did not even appreciate the scale of risks that (s)he was assuming or the likelihood of those risks materialising.

Perhaps the most widely supported proposal is to broaden the legal requirements to be applied to corporate Boards and/or senior executives to incorporate certain social responsibilities. Whereas this might salve the conscience of the relevant regulators, we doubt that it would be effective, for several reasons. First, so long as management is paid in the same fashion, the bonus culture, it will remain in their self-interest to maximise short-term equity valuations; and the shareholders to whom management ultimately answer will also have the same incentive. Second it would be hard ever to prove in a court of law that those required to follow wider social objectives had ex ante consciously chosen not to do so. Thus it would be extremely difficult to enforce such obligations by ex post sanctions. Third, it runs into the criticism so forcefully expressed by Milton Friedman in 1970, and more fully outlined in footnote 91 below, that such a measure would lead to an inappropriate confusion of political and business objectives.

Instead, our proposal, set out in Section IV, is to move to a system with two classes, or tiers, of equity holders; to wit 'insiders' with additional information about, and power to influence, managerial decisions, and 'outsiders', those without such powers. There are already distinctions in some cases between shares with voting rights, and those without; and there are many tiers of debt obligations. One of the main problems of unlimited, or multiple, liability was that it seemed unfair, and politically unacceptable, to penalize 'outside' shareholders, especially retail individual investors who had little knowledge, and no power to influence, the policies that had led to the bad outcome.

Thus our proposal is to apply a distinction between a class of 'insiders', who should be subject to multiple liability, and 'outsiders', who would retain limited liability, as at present. ${ }^{9}$ So, for the ordinary shareholder there would be no change. Such a scheme obviously involves making a distinction, which must be inevitably somewhat arbitrary, between 'insiders' and 'outsiders'. We discuss how such a border might be defined, and such other calibrations as might be necessary in Section IV. There is, to be sure, a particular problem with respect to (large) institutional investors. Sometimes they choose to behave passively, as if 'outsiders'; and sometimes they engage actively with management, as if 'insiders'; and they can even switch from one role to the other. We propose in this respect a mechanism for institutional self-selection.

\footnotetext{
8 Andreas Kokkinis, 'Corporate Law and Financial Instability', (London, UK: Routledge), (2018).

${ }^{9}$ Heny Hansmann and Reinier Kraakman in 'Towards unlimited liability for corporate tort' The Yale Law Journal, Vol. 100, No. 7 (May 1991), pp. 1879-1934 argue in favour of a distinction based on type of liability from the perspective of tort law.
} 
While we believe that such a two-tier equity system should be the ultimate objective, the transitional costs of moving there in one single step would be far too great. There is no experience of how such a two tier system might work, so it would be a step in the dark. It would involve a sudden change in the contractual status of all those now categorised as 'insiders', which would be strongly resented, politically opposed, and could reasonably be regarded as unfair.

So our actual, practical, proposal, borrowing from an idea put forward first by Conti-Brown, discussed at greater length in Section III, is to limit such a two-tier system to Systemically Important Financial Intermediaries (SIFIs), which could also be given the alternative of operating with a much higher equity ratio.

One advantage of this proposal is that it might be capable of extension to auditing firms and Credit Rating Agencies, even though they do not hold shares in the firms that they audit/rate. Also such a two-tier system could/should allow fines for corporate misconduct to be applied solely, or primarily, to 'insider' shareholders, and not be imposed (inappropriately) on all shareholders, including 'outsiders'. This would not only be much fairer, but also have a stronger, and more direct, incentive effect on management to prevent misconduct. This is discussed in Section V.

Indeed, one of the purposes of the exercise is to restore a sense of fairness with respect to the costs and benefits facing individuals placed in different circumstances. When a financial crisis, involving a corporate insolvency, occurs, lots of 'smaller' people, such as workers, trade creditors and small investors, lose a lot, whereas it appears that the senior mangers of the financial institutions at the heart of the crisis can walk away relatively unscathed. Even if the managers did nothing wrong in a legal sense, neither did the smaller people who got hurt. In our view, the political uproar following the Great Financial Crisis was not caused so much by the State stepping in to bail out the institution, but rather by the fact that the private sector managers, who were largely responsible, were not subject to much heavier sanction. ${ }^{10}$

Section VI concludes.

\section{Historical record of limited liability}

Commercial enterprises had been legally structured as partnerships with unlimited liability until the $19^{\text {th }}$ century. Limited liability was a legal innovation of the $19^{\text {th }}$ century. It became one of the constituents elements of the joint stock company (Société Anonyme, S.A. in France or Spain, Aktiengesselschaft or A.G. in Germany), though the advent of this corporate form preceded the advent of limited liability (the name 'company' is typically used in the UK, while the US uses the term 'corporation').

The principles of partnership and unlimited liability had been considered as 'natural and beneficent' in the early $19^{\text {th }}$ century, ${ }^{11}$ since they promoted responsibility and accountability.

\footnotetext{
${ }^{10}$ It is also possible to impose financial consequences on management via sanctions. However, as we further discuss below, a major problem is that the imposition of sanctions by regulatory bodies - in itself a time consuming exercise - has led in the UK to very few and generally small fines on individuals, notwithstanding the introduction of the Senior Management and Certification Regime (SM\&CR).

${ }^{11}$ See Paddy Ireland (2008), "Limited liability, shareholder rights and the problem of corporate irresponsibility", Cambridge Journal of Economics. 34 (5): 837-856,
} 
Under limited liability, a shareholder can participate in the growth of the company but his or her liability is restricted to the amount invested in the company. If the company as an entity endowed with legal personality ${ }^{12}$ goes bankrupt, the shareholders' liability remains limited to the value of their investments, and shareholders have no personal liability for the company's debts. Thus the company is liable for the rest of the debt obligations. ${ }^{13}$

While it is widely accepted that joint stock companies with limited liability and separate legal personality contributed to the expansion of the capitalist system, there have been misgivings from the beginning about the benefits of this legal form for banks (and insurance companies). Those misgivings have returned to haunt us in the aftermath of the global financial crisis.

As stated by Charles Dumas in his recent book on Populism and Economics, 'an awkward question exposed by the ebbing of the financial crisis is whether the limited liability company, a cornerstone of the world's economic system for more than a century, played a part in causing and prolonging that crisis and therefore now needs reform". ${ }^{14}$ Limited liability is after all 'a major privilege' that allows shareholders as well as senior directors or managers to enjoy the upside from their commercial activity while limiting their exposure to losses in the event of failure or bankruptcy ('skewed incentives'). ${ }^{15}$

History provides a range of different liability regimes, from unlimited liability to double or multiple liability and then to single limited liability. This Section II is divided into four subsections. Firstly, we examine the record of double liability for banks in the USA. Secondly, we focus on the UK experience with special mention to the collapse of City of Glasgow Bank. The last two subsections very briefly consider the history of double liability Canada and some examples of limiting liability in a few European jurisdictions.

Historical evidence supports our proposal for a different liability regime for banks that we refer to as 'intermediate' or 'partial' liability (a category between limited and unlimited liability) and which is an alternative to the current regime of shareholder limited liability.

\footnotetext{
12 The relationship between limited liability and the fiction of a company's legal personality requires further research which is beyond the scope of this paper.

${ }^{13}$ See Amy and David A. Westbrook, "Unicorns, Guardians, and the Concentration of the U.S. Equity Markets," 96 Nebraska Law Review 688 (2018) and https://papers.ssrn.com/sol3/papers.cfm?abstract id=3200415
}

The idea that shareholders ought to bear more responsibility ties into the fundamental anxiety of creating legal persons, that the fiction won't hold up under pressure. That the banks will dissolve, be floated, whatever, and real people will be hurt, but no real people will be responsible. So much of the $19^{\text {th }}$ century law, e.g., par value, $\mathrm{s} / \mathrm{h}$ appraisal rights, etc., can be seen as making sure the firm is really "there" for the $\mathrm{S} / \mathrm{H}$ and for third parties. See generally Morton Horwitz. Much of the $20^{\text {th }}$ century can be seen as the whittling away of such devices for making corporations more solid, in the name of entrepreneurship, risk taking, innovation, and the like. The classic relatively recent statement was the last decision in the tortuous Disney litigation, in which truly bad board decisions were ultimately defended under the business judgment rule, in order to ensure that capital would be put at risk, people would agree to direct such capital, etc. Amy Westbroook has gone so far as to argue that, absent serious self-dealing, the board's legal responsibility has, as a practical matter, all but disappeared. It simply isn't litigable in Delaware. See "Does Banking Law Have Something to Teach Corporate Law about Director Duties." http://washburnlaw.edu/profiles/faculty/activity/westbrook-amy.html

${ }^{14}$ See Charles Dumas, Populism and Economics, Profile books (2018), page 166.
${ }^{15}$ Ibid, page 166-167. 


\section{II.1 The US historical record on limited liability and the experience of double liability}

The first modern limited liability law was enacted by the State of New York in 1811 for manufacturing companies. ${ }^{16}$ New Hampshire followed in 1816, and Connecticut in 1818.

The US Congress, through the passage of the National Banking Act of 1863, established double liability for national banks, providing that "each shareholder shall be liable to the amount of the par value of the shares held by him, in addition to the amount invested in such shares" ${ }^{17}$ Double liability meant that shareholders could be assessed for an additional amount equal to the paid-in capital of the bank if the bank were to be placed into receivership. Thus, the actual amount of equity that acted as a buffer against losses from the depositors' perspective was more than the amount of paid-in capital and accumulated retained earnings.

"Following the implementation of the federal double liability system, States continued to adopt similar programs for their state-chartered banks and they implemented double liability rules for bank shareholders (...) Most of these state provisions were closely modeled on the National Bank Act". ${ }^{18}$ The federal structure of US Government led to a system of decentralized corporate law with single limited liability laws co-existing with double liability laws for banks in the $19^{\text {th }}$ and early $20^{\text {th }}$ century. As stated above, under double liability, bank shareholders were liable not only for the value of their investments, but also for the portion of a bank's debt in the case of insolvency. ${ }^{19}$

Single shareholder liability was adopted by banks in more rapidly growing States. States with more highly developed economies and banking systems, which had more to lose from banking instability, and states with a history of financial instability tended to adopt double liability in order to encourage more circumspect banking practices. ${ }^{20}$ It has been argued that "since risk-prone agricultural states were more likely to adopt double liability, and that since agricultural crises during the period were a principal cause of bank failures, in years of severe agricultural distress, double liability states would appear more risky than single liability states." ${ }^{21}$ In any case, given the flight of capital from States with unlimited or double liability to States with limited liability, the latter acquired greater popularity.

\footnotetext{
${ }^{16}$ See Kevin Forbes, "Limited Liability and the Development of the Business Corporation", Journal of Law, Economics \& Organization, Vol. 2, No. 1 (Spring, 1986), pp. 163-177, fn 4. https://www.jstor.org/stable/764920?seq=1\#page_scan tab_contents

${ }^{17}$ National Banking Act of 1863, ch. 58, 12 Stat. 665.

18 See Jonathan Macey and Geoffrey Miller, "Double Liability of Bank Shareholders: History and Implications" 27 Wake Forest L. Rev. 31, 1992, p. 37.

${ }^{19}$ Ibid, p. 33: "Double liability transforms shareholders from investors seeking to advantage themselves at the expense of other investors who benefit themselves by the decreasing the riskiness of these firms". See also Howard Bodenhorn, "Double Liability at Early American Banks", NBER Working Paper No. 21494, August 2015, revised January 2017.

${ }^{20}$ Richard Grossman, 'Fear and greed: The evolution of double liability in American banking, 1865-1930', (2007), Explorations in Economic History 44, 59-80, 61

${ }^{21}$ Ibid, (Grossman), 64
} 
The effect of the end of double liability was masked by the move by banks from making loans to holding government debt, ${ }^{22}$ as well as by state anti-branching regulations and the regulatory systems' inability to cope with a growing and more integrated and complex economy. ${ }^{23}$

The 1920s saw an unusually high number of bank failures. There were thirty-five clusters of suspended banks (182 suspended banks in all) between 1921 and 1929 largely in rural states. ${ }^{24}$ It may have been due to the over-expansion of agriculture arising from increased demand for produce in World War I. This was followed by an agricultural depression with consequential loan defaults. The 1926 banking panic in Florida and Georgia was, however, the result of a land boom in these states, and businesses linked to this including interstate roads, railways and ports. For example, in Georgia the 1926 series of runs was so severe (70 banks were closed within 3 days) that newspaper reporting was restricted. ${ }^{25}$

While there is some evidence of a correlation between the use of double shareholder liability and fewer bank defaults it is not clear if there is a causation link and, if so, in what direction causation runs. ${ }^{26}$ Moreover by the early 1920s in the US any relationship between the two had dissolved and banks were very exposed to both, agricultural price collapse and bank runs.

Bank failures multiplied between 1929 and 1933. As Macey \& Miller note, these failures ultimately resulted in political pressure that led to the abandonment of double liability. ${ }^{27}$ The creation of the Federal Deposit Insurance Corporation was seen by many as a better solution to bank runs than double liability. "In 1933 Congress repealed double liability for newly-issued national bank shares;

\footnotetext{
${ }^{22}$ Eugene White, Rethinking the regulation of banking: choice or incentives? (December 2010), mimeo, Rutgers University,

${ }^{23}$ Eugene White, The regulation and reform of the American banking system, 1900-1929, (Princeton University Press, 1983)

${ }^{24}$ Lee Davison and Carlos Ramírez 'Local banking panics of the 1920s: identification and determinants', (2014) Journal of Monetary Economics 66, 164-177

${ }^{25}$ Ibid.

${ }^{26}$ Anderson, Barth and Choi, 'Reducing Moral Hazard at the Expense of Market Discipline: The Effectiveness of Double Liability before and during the Great Depression', (2018), FDIC Center for Financial Research Paper No. 2018-05, 22 October, show that in the years 1926-1932 double liability did not seem to reduce banks' risktaking, as measured by capital and cash ratios. They ascribe this finding to a supposed decline in depositor monitoring of double liability banks.
}

But retail depositors generally have neither the capacity nor, in most cases, the incentive to monitor their own banks, preferring to leave this to regulators or other specialised monitoring agencies. We doubt, but do not know, whether the State-chartered banks of New York and New Jersey, the base for the econometric test, had much in the way of large, wholesale deposits.

As the authors note, p. 5, earlier studies had found that double liability "became less effective in the 1920s due to the broadening of stock ownership during the economic boom...." This was the era of the divorce between ownership and control, also see Adolf Berle and Gardiner Means, "The Modern Corporation and Private Property" (Transaction Publishers, New Jersey, 1932). Control was shifting to managers. At this juncture bank managers were, we believe, rarely given (double liability) stock options. Instead we surmise that their cash salary would be positively related to the size and profitability of their bank, while the worst that could happen to them if their bank did badly would be to lose their job, i.e. that their remuneration function was akin to that of a limited liability shareholder. So, as control shifted from a small group of closely connected shareholders to managers, the incentive of the latter would be to take advantage of the reputed safety of double liability to reduce capital and cash ratios.

${ }^{27}$ Supra, Macey \& Miller, p. 37. "As one author noted in 1936, the double liability effectively bankrupt[s] many innocent stockholders who have taken no part in the active management and control of the bank." 
and in 1935, it extinguished all double liability for national bank stock provided that a bank gave a six months notice of termination. Federal double liability was all but moribund after 1934". ${ }^{28}$

There is some evidence that double liability did serve to stabilise the US financial system, but the costs, including legal costs, of pursuing thousands of small shareholders to draw extra money from them, brought the whole system into disrepute when so many banks collapsed in the 1930s. ${ }^{29}$ The use of double liability declined during the 1930s following the lack of depositor confidence in the banking system and the introduction of federal deposit insurance via the Banking Act of $1933 .{ }^{30}$ The bankruptcies of many shareholders who had taken no part in the management of failed banks generated political pressure on States to repeal double liability laws. It appears that prior to the 1930s double liability shares had provided beneficial returns to shareholders but that this positive position started to reverse in the 1930s. In the period 1930-34 there was a substantial reduction in shareholder recoveries. ${ }^{31}$

There were of course other regulatory factors which influenced risk-taking at State-level including capital and reserving requirements and branching restrictions in addition to introduction of deposit insurance and more effective banking supervision. ${ }^{32}$ The dire economic situation in the Great Depression ${ }^{33}$ led to a general distrust in equity investments.

Notwithstanding the problems in administering the double liability rule,$^{34}$ some scholars continue to argue that the basic premise of double liability created a system of incentives and shareholder monitoring for banks, which instilled sound banking practices and limited reckless risk-taking. ${ }^{35}$

\section{II.2 UK experience of unlimited and limited liability}

Unlimited liability was the norm in the UK until the 1850s. The advent of joint stock companies following the passage of the Joint Stock Companies Act of 1844 did not limit shareholder liability. Indeed, creditors of a joint stock company could enforce by execution not only against the assets of the company but also against the property of any shareholder. In 1853 a Royal Mercantile Laws Commission was established to study modifications to liability of partners. As part of its evidence

\footnotetext{
${ }^{28}$ Ibid, 38.

${ }^{29}$ See Charles Calomiris has written about this. For a recent paper see Charles W. Calomiris and Elliot S.M, "Who owned Citibank? Familiarity Bias and Business Network Influences on Stock Purchases 1925-1929", NBER Working Paper 24431 http://www.nber.org/papers/w24431, March 2018. See also Charles W. Calomiris and Berry Wilson, "Bank Capital and Portfolio Management: The 1930s "Capital Crunch" and the Scramble to Shed Risk", Journal of Business, 2004, vol. 77, no. 3, 2004, the University of Chicago.

${ }^{30}$ Supra, Grossman, 64

${ }^{31}$ Berry Wilson and Edward Kane, 'The demise of double liability as an optimal contract for large-bank stockholders', (December 1996), NBER Working Paper Series, WP 5848

${ }^{32}$ Supra, (Grossman), 75

${ }^{33}$ See "The Key to Industrial Capitalism: limited liability", The Economist, $23^{\text {rd }}$ December 1991, https://www.economist.com/finance-and-economics/1999/12/23/the-key-to-industrial-capitalism-limitedliability "Shares were first issued in the 16th century, by Europe's new joint-stock companies, led by the Muscovy Company, set up in London in 1553 to trade with Russia. (Bonds, from the French government, made their debut in 1555.) Equity's popularity waxed and waned over the next 300 years or so, soaring with the South Sea and Mississippi bubbles, then slumping, after both burst in 1720. But share-owning was mainly a gamble for the wealthy few, though by the early 19th century in London, Amsterdam and New York trading had moved from the coffee houses into specialised exchanges." In 1932, "America's GDP was around 60\% of its 1929 value, $25 \%$ of the workforce out of work, and the Dow wavering at about one-seventh of its pre-crash high."

${ }^{34}$ Supra, Macey \& Miller, 39-55 for an excellent analysis of these problems.

35 Ibid. p. 32.
} 
gathering the Commission issued a questionnaire including questions related to banks, to which responses indicated a lower support for changing the liability laws in the case of banks. ${ }^{36}$ The responses reflected 'three perceived characteristics of banks: the special nature of bank's creditors, the effects of unlimited liability on the risk of a bank run (...) and the influence of unlimited liability on the quality of a bank's capital and its shareholders". ${ }^{37}$ The Commission's Report on the Mercantile Laws and Amendments to the Law of Partnership was published in 1854.

The first Limited Liability Act for companies was enacted in 1855. The legislature appeared to be suspicious of banks (and insurance firms) and thus they were excluded. ${ }^{38}$ As Ricardo eloquently wrote, the distinctive feature of the banker begins when he uses the money of others; as long as he uses his own money he is only a capitalist. ${ }^{39}$ As a result of the company law changes in 1855 there was a major rise in the number of limited liability companies to nearly 5,000 firms in England, and to an expansion in equity finance.

Shareholders in banks and insurance companies gained statutory permission for limited liability in 1862. "By the 1870s, there were still circa 70 English banks which were companies with unlimited shareholder liability and shares traded on stock markets. However, only seven English banks took advantage of the 1862 Act" which permitted limited liability. ${ }^{40}$ The reason why so few banks chose limited liability had largely to do with confidence and the avoidance of bank runs. The wellestablished banks expected that by staying with the unlimited liability system they would inspire greater trust in their customers. ${ }^{41}$ Both bank shareholders and depositors believed that unlimited liability made for a more stable banking system because the liability of shareholders was an effective constraint on risk shifting and excessive risk taking. ${ }^{42}$

A great concern in the 19th century was the 'spectral nature' of the joint stock company. In particular there was an ever present worry "that incorporated banks might evaporate and disappear since they were not real people" ${ }^{43}$ However, the position against limited liability began to change after the collapse in 1878 of the City of Glasgow Bank.

\footnotetext{
${ }^{36}$ Matthew Willinson, "Were banks special? Contrasting viewpoints in mid-nineteenth century Britain", Bank of England Staff Working Paper No. 755, September 2018

${ }^{37}$ Ibid. p. 8.

${ }^{38}$ As quoted by Paddy Ireland, an early critic of limited liability, Edward William Cox, had written in 1856 that the law of partnership had been: ... "[T] $[$ hat he who acts through an agent should be responsible for his agent's acts, and that he who shares the profits of an enterprise ought also to be subject to its losses; that there is a moral obligation, which it is the duty of the laws of a civilised nation to enforce, to pay debts, perform contracts and make reparation for wrongs. Limited liability is founded on the opposite principle and permits a man to avail himself of acts if advantageous to him, and not to be responsible for them if they should be disadvantageous; to speculate for profits without being liable for losses; to make contracts, incur debts, and commit wrongs, the law depriving the creditor, the contractor, and the injured of a remedy against the property or person of the wrongdoer, beyond the limit, however small, at which it may please him to determine his own liability". See Paddy Ireland (2008), "Limited liability, shareholder rights and the problem of corporate irresponsibility", Cambridge Journal of Economics. 34 (5): 837-856, https://academic.oup.com/cje/article/34/5/837/1700679

39 This citation of Ricardo is made by Walter Bagehot, Lombard Street (1873), [reprint edition by Arno Press, New York, 1978 of the 1915 ed. published by Smith, Elder \& Co., London] p.21.

40 John Turner, 'The development of English company law before 1900', (2017), Queen's University Centre for Economic History (QUCEH), Queen's University Belfast, Working Paper Series, No. 2017-01, 41

${ }^{41}$ Ron Harris, 'The private origins of the private company: Britain 1862 - 1907', (June 2013) Oxford Journal of Legal Studies, Volume 33, Issue 2, 339-378, 355

${ }^{42}$ Supra (Turner), 124-125. See also Jenks, The Migration of British Capital to 1875, pp. 274-275.

${ }^{43}$ David Westbrook, Between citizen and state; an introduction to corporation law, (Paradigm Publishers,

Boulder Colorado, 2007)
} 


\section{The Scottish Banking System and the collapse of the City of Glasgow Bank}

In the $19^{\text {th }}$ century Scotland had its own distinct banking system, different from the rest of the UK. Scotland had a large number of joint-stock banks but only the three chartered banks (Bank of Scotland, Royal Bank of Scotland and British Linen Company) had limited liability. ${ }^{44}$

There was a global recession through the 1870 s and into the 1890s. Known as the "long depression", it had swept from Eastern Europe and Germany to the UK and across the Atlantic where it brought to grief a group of the "robber barons". However, paradoxically, the origins of this global affliction may be found in the rapid growth of wheat production in the newly opened prairies under the Homestead Act 1862. US wheat production rose from 170,000 bushels each year in 1866 to 322,000 in 1873 at the start of the crisis. ${ }^{45}$ In parallel, the price of wheat fell from $\$ 2.95$ per bushel in 1866 to $\$ 1.78$ in 1873. ${ }^{46}$ Much of the wheat was shipped to Europe where it under-cut the price of grain from Eastern Europe and Russia resulting in economic destitution and was, in part, responsible for the start of waves of immigration to America through the rest of the century and beyond.

Against this background, the City of Glasgow Bank had expanded its lending overseas during the boom of the 1860s. It invested in illiquid industrial assets and its portfolio was very concentrated. Other banks had reduced their lending to industry and moved their funds to the liquid London money market. ${ }^{47}$

Liquidity pressures had been building in the UK's banking system from early 1878 and this contraction may have been the issue which finally put paid to the City of Glasgow Bank. ${ }^{48}$

The failure of the City of Glasgow Bank was due to a mixture of unscrupulous directors and poor corporate governance. The directors lent the bank's money to themselves and their associates and were not able to repay what had been borrowed. Within professional circles in Scotland, the bank was "viewed with suspicion and regarded as a risky institution...the City of Glasgow Bank was never highly esteemed outside the circle of its dupes and seems to have been a long-continued fraud". ${ }^{49}$ It can be argued that problems are likely when bank ownership and lending policies start to diverge. ${ }^{50}$ This may necessitate either a change in corporate governance or much more stringent regulatory supervision or both.

The high concentration of the bank's lending is evident in that "just four borrowers accounting for $75 \%$ of total loans at the time of collapse. These four were all local businesses deeply involved with Indian and Australasian trade: James Morton \& Co., John Innes Wright \& Co., Smith Fleming \& Co. and James Nicol Fleming." ${ }^{51}$ There were land reclamation projects for port development in Bombay

\footnotetext{
44 Lawrence White, Free banking in Britain: theory, experience and debate, 1800-1845, (Second edition, Institute of Economic Affair, London, 1996), 37-38

45 Robert Sobel, Panic on Wall Street, (first published in 1968, TT Dutton, New York, 1988) 157

46 Ibid, 158

${ }^{47}$ Dieter Ziegler, 'The banking crisis of 1878: some remarks', (1992) Economic History Review, XLV, 1, 137144,143

${ }^{48}$ Supra note 2, (Collins) 520

${ }^{49}$ David Evans 'Major and minor British banking crises since 1800' in John Turner (ed), Banking in crisis: the rise and fall of British banking stability, 1800 to the present, (Cambridge University Press, 2014), 66-101, 86

${ }^{50}$ Henry Hansmann and Mariana Pargendler 'The evolution of shareholder voting rights: separation of ownership and consumption', (2014). Faculty Scholarship Series. 4721, Yale Law Journal, 977

${ }^{51}$ Supra note 4, (BoE), 25
} 
as well as lending to finance the acquisition of land companies in Australia and New Zealand and railways in the US. ${ }^{52}$

At the time of its collapse, the bank had liabilities of $£ 12.4 \mathrm{~m}$ and assets of only $£ 7.2 \mathrm{~m}$ and the shareholders were required to make up the difference. All the depositors were repaid and the other Scottish banks honored all the fiat notes issued by the bank since some of the Scottish banks had note issue rights. By the time the assessment process was over only 254 of the 1,819 shareholders remained solvent. "Nearly 2,000 families suffered severe loss; many were ruined. In addition, another Scottish bank, the Caledonian, found itself a direct casualty of the unlimited liability rule." 53 The shareholders were largely concentrated in Glasgow and Edinburgh and the effects on the small communities seared the memory of the Scottish "central belt".

The penury into which City of Glasgow Bank shareholders had been thrown elicited a considerable amount of public sympathy. "A great majority of them, perhaps a thousand out of the twelve hundred and fifty, have been totally ruined by a catastrophe which they foresaw as little as they might have done an earthquake or a landslip. A large section of them are most respectable persons, in the decline of life, who have retired from trades or professions to live on their small realised properties, who cannot return to work again with any chance of success, and who have before them no prospect, except the poor-house or the grudging charities of relatives or friends. Hundreds have wives and children dependent on their incomes, and in all cases probably the ruin is that of households rather than of individuals." ${ }^{4}$ The extensive press reporting "portrayed the shareholders as socially vulnerable and financially ruined investors, with small shareholdings. The public were reported as viewing the failure of the City of Glasgow Bank and the impact on its shareholders as a national tragedy." 55 The evidence of the bank's directors' incompetence led to the Glasgow Herald describing the directors" "shipwreck of a noble institution; they have recklessly divided the plunder among themselves and their friends; and they have inflicted misery and ruin on thousands of innocent sufferers." 56 "The Glasgow correspondent of the London Times wrote: "the parties chiefly concerned, and on whom the weight of the calamity will fall, are small merchants, divines and doctors of Medicine, none of whom can be classed among the wealthy and very many of whom had invested their savings of a lifetime". ${ }^{57}$ The Times also reported that almost all the lawyers and accountants in Glasgow had kept clear of the bank; "those best qualified to advise investors would have nothing to do with its shares" and it was the lesser well connected and knowledgeable who were caught as shareholders in the failed bank. ${ }^{58}$ Six directors and the General Manager went to prison for false accounting. ${ }^{59}$

The newspapers may however have overstated the destitution caused by the bank's failure and the call on shareholders. For example, on $5^{\text {th }}$ November 1878 the Times described "the destitution and

\footnotetext{
${ }^{52}$ Ibid

${ }^{53}$ Supra note 9, (Collins), 505.

${ }^{54}$ The Spectator, 2nd November 1878, Vol. 511, Issue 2627, 1363.

55 Richard Button, Samuel Knott, Conor Macmanus and Matthew Willison, 'Desperate adventurers and men of straw: the failure of City of Glasgow Bank and its enduring impact on the UK banking system', (2015) Bank of England Quarterly bulletin, 27

${ }^{56}$ Forbes Munro, in the chapter, 'The failure of the City of Glasgow Bank, 1878-82' in Maritime Enterprise and Empire, 1823-1893, (Boydell \& Brewer, Boydell Press, Woodbridge, Suffolk, 2003), 254

${ }^{57}$ Leo Rosenblum, 'The failure of the City of Glasgow Bank', (Dec 1933), The Accounting Review, Vol. 8, No. 4, 285-291, 290-291

58 Ibid, (Rosenblum), 290-291

${ }^{59}$ Supra note 4, (BoE), 25
} 
bereavement which this unfortunate calamity would entail and the list of shareholders embraced a terrible proportion of cases where the loss could mean nothing but absolute and hopeless beggary" and the Economist of 27th December 1879, stated that in "hundreds and thousands of cases homes have been broken up, health and life destroyed, dismay and ruin spread over towns and parishes, sons and daughters left penniless." ${ }^{60}$ The newspapers, in effect, highlighted to their readers that without a rapid change to the shareholder liability law that it could be them next time a bank failed.

The traumatic collapse of the City of Glasgow Bank (as one of the largest unlimited liability banks in the UK) in October $1878^{61}$ shifted the mood against unlimited liability and led to the passage of the Companies Act of $1879^{62}$. This Act created the concept of reserve liability "which meant that banks could have extended liability, but less than unlimited liability; for example, some banks had double liability (i.e., for every $£ 100$ of capital shareholders had paid in, they were liable for another $£ 100$ ) and others had various multiples of paid-up capital. ${ }^{63}$ This reserve liability could be called up only in the event of a bank's failing, unlike uncalled capital which also could be called up at the discretion of directors. All banks quickly limited their liability after the passage of the 1879 Act, but reserve liability - under which a shareholder was liable for a bank's debt up to some multiple of its shareholding - remained a feature of British banking until the mid-1950s" ${ }^{64}$ which meant that banks could have extended liability but less than unlimited liability. ${ }^{65}$ Reserve liability was thus a capped or limited liability over and above paid-up capital owed by shareholders to the bank which could be called on to make good any deficit on the bank's liquidation.

The existence of unlimited lability may have restricted the size of banks since a large balance sheet increased the risk of large losses for shareholders and, consequently, discouraged investment in banking. Further, as was seen with the City of Glasgow Bank the link between shareholders and managers had ceased (principal/agency problem) and no-one, including depositors, appeared to have scrutinised the wealth or otherwise the list of shareholders. The development of limited liability banks in the 1880s "removed these barriers to the emergence of larger banks, contributing to a wave of bank mergers in the late 19th and early 20th century." mandatory independent audits. ${ }^{67}$

Another interesting historical precedent is provided by the of the Companies Act of 1948, sections 202 and 212. According to Section 202 (which survived into the Companies Act 1985 as Section

\footnotetext{
${ }^{60}$ Quoted in Thomas Lee, 'A helpless class of shareholder': newspapers and the City of Glasgow Bank failure', (2012) Accounting History Review, Vol. 22, Issue 2, 143-159, 143, https://www.tandfonline.com/doi/full/10.1080/21552851.2012.681125?src=recsys. (accessed 11th June 2018) ${ }^{61}$ Michael Collins, 'The banking crisis of 1878', (Nov., 1989), The Economic History Review Vol. 42, No. 4, 504-527, 504-505

62 John Turner, Banking in crisis: the rise and fall of British banking stability, 1800 to the present, (Cambridge University Press, 2014). The Overend Gurney collapse in 1866, Guy Morton pointed out in correspondence, was of an institution which had got in a precarious situation as an unlimited partnership and was trying to bail itself out by raising new money (on a false prospectus).

${ }^{63}$ Willinson, supra note, at p. 10 notes that while Walter Bagehot was "against unlimited liability", he "did favour shareholders having double or triple liability".

${ }^{64}$ Turner, supra note, at p. 132. Willinson, supra, at note 5 and Section 3.

${ }^{65}$ Graeme Acheson, Charles Hickson and John Turner, 'Does limited liability matter? Evidence from nineteenth-century British banking’, (2006) XIV International Economic History Congress, Helsinki, http://citeseerx.ist.psu.edu/viewdoc/download?doi=10.1.1.508.7416\&rep=rep1\&type=pdf

(accessed 7th June 2018)

${ }^{66}$ Supra note 4, (BoE), 30

${ }^{67}$ The Companies Act 1879, (42 \& 43 Vict c 76). The Institute of Chartered Accountants in England and Wales was founded in 1880 with its members providing these independent audits.
} 
503), "in a limited company the liability of the directors or managers, or of the managing director, may, if so provided by the memorandum, be unlimited." Section 212, the enforcement provision, (which became section 503 of the 1985 Act, and, shortly after that, section 75 of the Insolvency Act 1986) provided a free-standing mechanism for enforcing this liability: A director or manager with unlimited liability "shall, in addition to his liability (if any) to contribute as an ordinary member, be liable to make a further contribution as if he were at the commencement of the winding up a member of an unlimited company". ${ }^{68}$ This Section was repealed from 1st October 2009 by the secondary legislation introducing the Companies Act 2006 (the Companies Act 2006 (Consequential Amendments, Transitional Provisions and Savings) Order 2009 (S.I. 2009/1941), arts 2(1), 8 (Sch 1 para 75(4)), which appears to confirm that the abolition must have been part of the 2006 reforms.

This historical precedent constitutes a working example of a structural incentive which avoided one of the main drawbacks of unlimited liability, namely that it is very imperfectly targeted. It was probably dropped by the Company Law Review on the ground that it was never used. As Guy Morton notes, if so, that does not necessarily prove that it was a bad idea - merely that it was unattractive to a group of people - prospective managers - who exercised a dominant influence over the structure chosen for institutions. In fairness to those people, though, the unlimited liability of managers had the additional drawback of being "all or nothing" and of containing no mechanism for tempering liability by reference to culpability, so they can hardly be blamed for shying away from it. ${ }^{69}$

There is at least one surviving UK bank with unlimited liability - C Hoare \& Co. - which is an unlimited company and the shareholders are also the managers. ${ }^{70} \mathrm{C}$ Hoare $\&$ Co. prides itself in having a conservative and personal ethos and in encouraging a long term outlook for their customer relationships and business decisions, one that tries not maximize profits, but to optimize quality. Their purpose is "to be good bankers and good citizens". ${ }^{71}$

The knowledge of unlimited liability prompts partners to be cautious about the criteria and process for admission to partnership (this is still how many law firms structure themselves), and to aim for dual or multiple oversight of very large and complex matters. ${ }^{72}$ But in this context also unlimited liability can have very harsh effects, particularly in cases of partner fraud. (The example of Sir Walter Scott, who spent the latter part of his life writing to pay off creditors of a firm of which he had been a sleeping partner, provides a cautionary note.)

\footnotetext{
68 Thanks to Guy Morton for observations on this point.

69 Thanks to Guy Morton for observations on this point

${ }^{70} \mathrm{C}$. Hoare \& Co is the oldest bank in the UK and maintains close family ownership of the firm since the 17 th Century. Five of the board directors are members of the same founding family. They and two other family members, are the only shareholders. They are known as "partners" and each has unlimited liability. https://www.hoaresbank.co.uk/sites/default/files/styles/CHC\%20Cons\%20Accounts\%202018 Signed.pdf The bank is very small operating in a niche very high-net-worth market and conservatively run, in terms of capital, liquidity and lending practices. It has only 371 employees with two branches (as of 31 March 2018). The bank's Common Equity Tier 1 ratio of over $21 \%$ is significantly higher than the average of the large UK banks (which are structured as PLCs). The bank keeps a significant part of its assets at the Bank of England (£1.2 Bn, just over $25 \%$ of all its assets). Almost all the other assets consist of loans to customers ( $£ 3.3 \mathrm{Bn})$..

${ }^{71}$ We thank Alexander Hoare, CEO of C Hoare and Co, for observations on this point.

${ }^{72}$ The extent to which the abandonment of the traditional partnership structure by the major US investment banks (the last to become incorporated as a public company being Goldman Sachs in 1999) contributed to shifting industry expectations as regards levels of remuneration and risk-taking is a subject which deserves further study.
} 
As the City of Glasgow Bank demise illustrated, unlimited liability for shareholders fell into disrepute because it failed to address the agency problem and thus punished the innocent without deterring or punishing the guilty. It is however an effective driver of behaviour in a partnership because here the agency problem either does not exist or is tightly controlled - in an unlimited partnership, the individuals who effectively direct the business are also among the principal individuals who will suffer in the event of failure. But once a business moves from being a true partnership to being a company where ownership and management are in separate hands, the effectiveness of unlimited liability as a deterrent is reduced and the scope for creating injustice and hardship increases.

The scope of our proposal of partial shareholder liability is limited to directors/managers. ${ }^{73} \mathrm{We}$ are aware that with an ordinary share structure, unlimited liability could exacerbate the serious "agency" problem which already exists. In general shareholders' ability to control management's activities is quite limited, given the vast difference of knowledge between the two. The experience of the Lloyd's insurance market in the late 1980s and 1990s is a cautionary example: many unlimited liability Names were ruined, while their agents suffered no more than loss of income.

\section{3 A brief assessment of the Canadian experience of shareholder double liability}

"Double liability was an inherent part of the Canadian banking system almost right from its creation". ${ }^{74}$ Under the double liability rule in Canada, in the case of bank failure, bank shareholders were responsible for twice the amount of their subscribed shares, that is for the amount of their subscribed shares and for an additional amount not larger than the par value of their shares. "Facing higher possible losses, bank shareholders are likely to become more risk averse under the double liability rule, as compared to the single liability assessment leading to lower risk taking". ${ }^{75}$ Between 1868 and 1881 double liability assessments were successful levied on the shareholders of two of the eight banks that failed; between 1883 and 1899 there were "nine bank failures and double liability was enforced in four cases; and in the period 1905-1923, there were nine bank failures and double liability was collected in eight cases." Across all these periods, the successful collection rate of the double liability averaged $59 \%$ of the paid-up capital compared with $49 \%$ in the US. ${ }^{76}$

Canadian shareholder double liability was phased out between 1934-1950. This led to an increase in bank leverage "...mainly due to their shift towards investment in liquid government securities". The enhanced regulation and supervision of chartered banks "created entry barriers for potential new competitors. That led to the development of oligopoly in the Canadian banking market" ${ }^{77}$ Michael

\footnotetext{
${ }^{73}$ Unlimited liability in relation to banks presents a further challenge: that in the circumstances of a modern bank it is too powerful an incentive and that is why we propose a system of intermediate liability. The reality of modern banking is that since the affairs of a modern bank are too complex, there might be little incentive for a prudent person to assume the responsibilities of management at all if that entails strict liability for the consequences of failure. Liability may also be tempered by the traditional 'has acted honestly and reasonably and ought to be excused' power of exoneration for misfeasance liability. Thanks to Guy Morton for observations on this point.

${ }^{74}$ Anna Grodecka and Antonis Kotidis, 'Double liability in a branch banking system: historical evidence from Canada', (2016), Working Paper Series 316, Sveriges Riksbank (Central Bank of Sweden), 4

75 Ibid. 2

76 Ibid, 4

${ }^{77}$ Ibid, 30
} 
Bordo describes this as a "grand bargain whereby the chartered banks would provide financial stability in exchange for the Canadian government limiting entry to the industry." 78

\section{4. Brief reference to other jurisdictions}

Under Swiss law, most banks are organised as sociétés anonymes. ${ }^{79}$ Swiss law has a very strict notion of sociétés anonymes (Aktiengeslleschaften). Art. 680(1) of the Code of obligations states: "A shareholder may not be required, even under the articles of association, to contribute more than the amount fixed for subscription of a share on issue". Until relatively recently, there were Swiss private bankers, ie natural persons exercising the banking business (generally restricted to investment services) in some form of partnership. Such bankers were liable with all their personal assets for any liability of the bank. There would also be limited partners (commanditaire) whose liability was limited to the amount of their commandite.

In civil law jurisdictions, the corporate form of the société en comandite in France or Sociedad en comandita (Sociedad comanditaria) in Spain or Kommanditgesellschaft in Germany permits limited partnership business entities in which partners with unlimited liability coexist with partners whose liability is limited to their fixed contributions to the partnership. These provide further examples of the possibility of establishing different categories of financial liability that coexist together under the same corporate structure.

Coming back to Switzerland, private bankers such as Pictet, Lombard et Mirabaud, retained that legal structure for their Swiss operation until 2014, when they transformed it into sociétés anonyme. (All other entities in their group were already companies limited by shares). They retain an element of partnership at the holding level, where they are protected by the limited liability of their many operational subsidiaries, including the flagship Swiss bank. ${ }^{80}$

The idea of financial liability 'with teeth' (intermediate liability) attached to senior bank managers provides an innovative solution that not only enhances individual accountability (correct bank incentives) but also contributes to financial stability, considered in the aftermath of the global financial crisis as a public good. ${ }^{81}$

Though the EC Twelfth Council Company Law Directive ${ }^{82}$ of 1989 requires Member States to make available legal structures for individuals to trade with limited liability (this was implemented in England and Wales by the Statutory Instruments 1992/1699), the EU provides an interesting example of the increasing differential corporate and regulatory treatment of banks as compared to other companies. Regulation has expanded exponentially in the banking sector over the last two decades in the EU (and beyond). Furthermore, special rules in competition and state aid point to the continuous

\footnotetext{
${ }^{78}$ Michael Bordo, Angela Redish, and Hugh Rockoff, 'Why didn't Canada have a banking crisis in 2008 (or in 1930, or 1907, or ...)?', (2011) NBER Working Paper No. 17312, http://www.nber.org/papers/w17312

${ }^{79}$ A number of them distribute shares or share options to their directors and some top employees, or allow them to buy shares at a discounted price. However, these shares do not include some potential liability for these special shareholders. The way it is now done is a contract (and some form of escrow where necessary) which allows the company to claw back the shares (or cancel the options) in case of certain defined events happen. Thanks to Luc Thevenoz for information on points of Swiss law.

${ }^{80}$ Thanks to Luc Thévenoz for information on points of Swiss law.

${ }^{81}$ There are of course a number of design issues which require further research. For example for liability to stick to the right person, it would require a prohibition to sell the shares for a given period of time. Perhaps the same result might be achieved by way of a contract with the manager to whom (ordinary) shares or options are issued. If we want the liability to be potentially greater than the value of the shares, a contract could also achieve that. ${ }^{82}$ https://eur-lex.europa.eu/legal-content/EN/ALL/?uri=celex:31989L0667
} 
specialty of banking and emphasize the need to design an adequate system of incentives that minimizes excessive bank risk taking to the detriment of society.

\section{Alternative Proposals}

There is a vast literature on potential improvements/changes to the business structure and governance of public corporations in general, and of commercial banks in particular. Rather than attempting to wade through all of this, in this Section we focus on the three recent sets of proposals in this field by Conti-Brown, Schwarcz and Kokkinis. ${ }^{83}$

\section{III.1 Elective Shareholder Liability}

Conti Brown ${ }^{84}$ proposes to solve the problem of bailouts by means of a legal mechanism he calls 'elective shareholder liability' which he claims is less intrusive and more effective than the regulatory solutions of Dodd-Frank.

Elective shareholder liability gives shareholders of systemically important financial institutions (SIFIs) the choice between reducing the firm's leverage by increasing capital significantly or by creating a bailout exception to the SIFI's limited liability status, such that the government can recoup the losses associated with any taxpayer bailout from the SIFI shareholders directly. By having shareholders instead of taxpayers cover the ultimate costs of the bank's failure, the incentive structure gets radically altered.

Elective shareholder liability could be structured as a governmental collection, similar to a tax assessment, for the recoupment of all bailout costs against the shareholders on a pro rata basis. The proposed structure would also give the government the authority to declare the shareholders' use of the corporate form to evade liability null and void, and would require that shareholders who litigate against collection and subsequently lose pay treble damages, including the government's litigation costs. Elective shareholder liability anticipates the development of a derivatives market that would insure shareholders against liability, the price of which would contain more relevant information about risk concentration than is presently available in the capital markets.

Conti-Brown points out the ex ante and ex post benefits of elective shareholder liability. Ex ante, it requires directors and officers who are significant shareholders to increase self-monitoring. Ex post, it creates a fund that can be used to reimburse taxpayers at least partially for the costs of bailouts.

Elective shareholder liability draws on the partnership structure of investment banking that dominated the field throughout its history, until the late twentieth century. That structure provided for unlimited personal liability in the event of bank failure. Though the complexity and size of modem investment banks make a simple return to partnerships unlikely, elective shareholder can accomplish some of the same goals.

Conti Brown's proposal focuses on placing extra liability on those who have the information and power to make the decisions for good or ill. However, by imposing elective shareholders' liability on

${ }^{83}$ Though others have written about this, given our ongoing dialogue with Peter Conti Brown and Steven Schwarcz we considered it pertinent to refer to their proposals. As for Kokkinis' book, it is a lucid explanation of the problems, which complements our own, though we go further than Kokkinis in terms of suggesting solutions to the problems at stake.

${ }^{84}$ See Peter Conti Brown, "Elective Shareholder Liability” 64 Stan. L. Rev. 4092012 
every shareholder in large banks, this solution may run into exactly the same problem as hit double liability in the US in the 1930s, i.e. having to chase up and extract money from many small shareholders, and/or make the return to capital significantly lower on large SIFI banks than on any other public company. Unless one thinks, perhaps for other reasons, that a differential penalty on really big banks is a good idea in any case, then we believe his proposal is less focussed and less efficient than our own. Our proposal also allows us to impose sanctions on other bodies with information and power to control companies, which are not shareholders, such as accountancy (audit) firms and Credit Rating Agencies. ${ }^{85}$

\section{III.2 Public governance duty}

Steven Schwarcz argues that limited liability should be redesigned to better align investor and social interests for shadow-banking firms and advocates a public governance duty. ${ }^{86}$

The thrust of his public governance duty proposal is as follows: Market failures encouraging excessive SIFI risk-taking stem from the shareholder-primacy model of corporate governance. Therefore, the most direct way of correcting those failures (and controlling excessive risk-taking) would be to modify that model by imposing some type of a public governance duty that requires SIFI managers to also consider the public consequences of their firm's actions.

Proposing such a duty would engage the longstanding debate whether corporate governance law should require a duty to the public. The accepted wisdom is not to require such a duty because corporate profit maximization provides jobs and other public benefits that exceed any harm. The assumption underlying that wisdom is that any significant public harm would be prohibited by other law or internalized through tort law. That assumption fails, however, for systemic public harm.

Schwarcz examines the merits and design, as well as the possible costs and benefits, of imposing a public governance duty ${ }^{87}$ Such a duty could be performed, for example, by a SIFI's risk committee, including risk committees mandated by post-crisis financial regulation. Most such risk committees, however, are not yet required to consider systemic risk or public harm. For example, risk committees required under the Dodd-Frank Act are only mandated to focus on risks to the SIFI itself, not to the

\footnotetext{
${ }^{85}$ A. Admati, P. Conti-Brown and Paul Pfleiderer, 'Liability Holding Companies', 59 UCLA L. Rev. 852 (2012). further consider changes to the governance of financial institutions in order to decrease the likelihood of taxpayers' bail-outs the US context. They propose an increased-liability version of the bank's equity via the introduction of a new kind of financial institution: liability holding company (LHC) which would be subject to a unique regulatory regime supervised by the Federal Reserve.

${ }^{86}$ See S. Schwarcz, "Misalignment: Corporate Risk-Taking and Public Duty," 92 Notre Dame Law Review 1 (Nov. 2016); also available at http://ssrn.com/abstract=2644375 and "Too Big to Fool: Moral Hazard, Bailouts, and Corporate Responsibility," 102 Minnesota Law Review 761 (2017) at http://ssrn.com/abstract=2847026 . See also Schwarcz, "Systematic Regulation of Systemic Risk", forthcoming in Wisconsin Law Review, Volume 2019, Issue No. 1, currently available at https://ssrn.com/abstract=3233666)

87 The proposed realignment of private and public interests under a public governance duty is different from the regulatory responses to the financial crisis that attempt to mitigate excessive risk-taking by aligning managerial and investor interests. Requiring managers of systemically important firms to account for systemic externalities in their governance decisions would help to correct this misalignment between private and public interests. That, in turn, would help to reduce excessive risk-taking. Managers of systemically important firms should have a duty to society (a "public governance duty") not to engage their firms in excessive risk-taking that leads to systemic externalities. See Schwarcz, Too Big to Fool: Moral Hazard, Bailouts, and Corporate Responsibility, 102 Minnesota Law Review 761 (2017), pp 787-792.
} 
public. Even the guidelines of the Basel Committee on Banking Supervision merely require SIFI managers to "look after the interests of the bank as a whole" and do not require them to take into account the possibility of systemic externalities.

The thrust of Schwarcz's proposals on how limited liability should be redesigned to better align investor and social interests for shadow-banking firms ${ }^{88}$ is as follows: Limited liability is not always optimal for firms that make up the shadow banking system. It motivates investor-managers of those firms to take risks that could generate outsized personal profits, even if that greatly increases systemic risk. The law does not effectively mitigate these systemic externalities. Tort law, for example, traditionally helps to mitigate non-systemic externalities resulting from limited liability by empowering injured third parties to whom the torteasor owes a duty of care to sue for harm that is a causal and foreseeable consequence of the tortfeasor's actions. Systemic harm, however, affects a wide range of third parties in unpredictable ways; it is neither directly causal nor clearly foreseeable. To mitigate systemic externalities, Schwarcz argues that limited liability should be redesigned for investor-managers of shadow banking firms. Any such redesign must balance the need to increase liability sufficiently to reduce systemic risk with not discouraging investment. The redesign should also minimize costs by discouraging the need to engage in cross-investor monitoring. These competing goals may well be achievable by restricting the increased liability to a capped multiple of the original investment, such as double liability.

Regardless of how limited liability is redesigned, Schwarcz says that it faces the dilemma that investor-managers would have relatively little incentive to monitor and guard against their firm's potential to trigger systemic risk if, as indicated, tort law bars injured parties from recovering damages. According to Schwarcz, a possible solution to this dilemma would be to couple the redesigned limited liability with a privatized systemic risk fund - which would be used to mitigate systemic harm - into which systemically risky shadow banking firms would be required to contribute. If an investor-manager's firm had insufficient capital to make these contributions, the investormanagers would become personally liable for at least a portion of the insufficiency, thereby motivating them to monitor and help control their firm's systemically risky behavior.

An ultimate question for any redesign of limited liability is empirical: will its benefits exceed its costs? The answer to that question will depend according to Schwarcz on the actual mechanics of the redesign, and their real-world impact on risk-taking and investment.

Schwarcz also suggests structuring mid-level executive incentive schemes to include more drastic deferral and malus elements which tie remuneration more effectively to long term outcomes. ${ }^{89}$ Secondary-management conflicts are an intra-firm principal-agent failure. It arises because secondary managers are almost always paid under short-term compensation schemes, misaligning their interests with the long-term interests of the firm. Complexity exacerbates this problem by increasing information asymmetry between those managers, who often are technically sophisticated, and the senior managers to whom they report. Prior to the financial crisis, for example, financial firms began compensating secondary managers not only for generating profits but also for generating profits with low risks, as measured by the VaR, or value-at-risk, model for measuring investment-portfolio risk. Secondary managers turned to investment products with low VaR risk profile, like credit default swaps that generate small gains but only rarely have losses. They knew, but did not always explain to

\footnotetext{
${ }^{88}$ Schwarcz,"The Governance Structure of Shadow Banking: Rethinking Assumptions About Limited Liability," 90 Notre Dame Law Review 1 (2014); also available at http://ssrn.com/abstract=2364126.

${ }^{89}$ Schwarcz, "Conflicts and Financial Collapse: The Problem of Secondary-Management Agency Costs," 26 Yale J. on Reg. 457 (2009); also available at http://ssrn.com/abstract_id=1322536.
} 
their superiors, that any losses that might eventually occur would be huge. The resulting losses ultimately jeopardized the solvency of numerous major financial institutions.

According to Schwarcz, regulation should require SIFIs to mitigate these conflicts by paying secondary managers under longer-term compensation schemes-e.g., compensation subject to clawbacks or deferred compensation based on long-term results. In practice, however, that solution would confront a collective action problem: firms that offer their secondary managers longer-term compensation might be unable to hire as competitively as firms that offer more immediate compensation. Because good secondary managers can work in financial centers worldwide, regulation may also be needed to help solve this collective action problem not only within, but also across, nations.

Schwarcz also examines behavioral limitations on the effectiveness of macroprudential financial regulation ${ }^{90}$, questions why bank executives were not held personally liable for the GFC, ${ }^{91}$ and argues that that regulation cannot prevent systemic collapses, so macroprudential regulation should be designed to also mitigate the impact of such (inevitable) collapses. $^{92}$

Moreover Schwarcz' proposals would still seem to run counter to Milton Friedman's arguments as set out in his New York Times Magazine (September 13, 1970) where he explains why in his view the social responsibility of corporate executives is to increase profits. ${ }^{93}$

\footnotetext{
${ }^{90}$ Schwarcz, "Regulating Complacency: Human Limitations and Legal Efficacy," 93 Notre Dame Law Review 1073 (2018), also available at http://ssrn.com/abstract=2875030.

${ }^{91}$ Schwarcz, "Excessive Corporate Risk-Taking and the Decline of Personal Blame," 65 Emory Law Journal 533 (2015), also available at http://ssrn.com/abstract=2553511.
}

92 Schwarcz, Regulating Ex Post: How Law Can Address the Inevitability of Financial Failure" (with Iman Anabtawi), 92 Texas Law Review 75 (2013); also available at http://ssrn.com/abstract=2271587.

${ }^{93}$ https://www.nytimes.com/1970/09/13/archives/article-15-no-title.html "What does it mean to say that the corporate executive has a "social responsibility" in his capacity as businessman? If this statement is not pure rhetoric, it must mean that he is to act in some way that is not in the interest of his employers. For example, that he is to refrain from increasing the price of the product in order to contribute to the social objective of preventing inflation, even though a price increase would be in the best interests of the corporation. Or that he is to make expenditures on reducing pollution beyond the amount that is in the best interests of the corporation or that is required by law in order to contribute to the social objective of improving the environment. Or that, at the expense of corporate profits, he is to hire "hardcore" unemployed instead of better qualified available workmen to contribute to the social objective of reducing poverty.

In each of these cases, the corporate executive would be spending someone else's money for a general social interest. Insofar as his actions in accord with his "social responsibility" reduce returns to stockholders, he is spending their money. Insofar as his actions raise the price to customers, he is spending the customers' money. Insofar as his actions lower the wages of some employees, he is spending their money.

The stockholders or the customers or the employees could separately spend their own money on the particular action if they wished to do so. The executive is exercising a distinct "social responsibility," rather than serving as an agent of the stockholders or the customers or the employees, only if he spends the money in a different way than they would have spent it. But if he does this, he is in effect imposing taxes, on the one hand, and deciding how the tax proceeds shall be spent, on the other.

This process raises political questions on two levels: principle and consequences. On the level of political principle, the imposition of taxes and the expenditure of tax proceeds are governmental functions. We have 
We shall explain in the following Section why this (Friedmanian) critique does not apply to our proposal.

\section{III.3 Kokkinis}

In a recent book on "Corporate Law and Financial Stability" ${ }^{94}$ Kokkinis exposes the misalignment between the conventional UK corporate law framework and the pursuit of the objective of financial stability. In particular, he criticises the features of limited liability, separate corporate personality and shareholder profit maximisation associated with the plc societal form, since they create incentives for excessive bank risk-taking. The analytical framework, drawing on the classic separation between ownership and control, whereby shareholders are the principals and managers the agents, pits the private interests of bank managers and shareholders against the public interest in financial stability.

Kokkinis suggests the imposition of additional duties on managers through tougher legal requirements and proposes a mechanism for opening up directors and senior management to civil suit in the case of failure.

Overall, the review of accountability mechanisms establishes that financial institution directors and senior managers who follow profit maximisation strategies entailing excessive risk-taking, but are in good faith, are still unlikely to face personal liability despite the reinforced powers of regulators to impose sanctions on individuals and the introduction of criminal liability for taking a risky decision that causes the failure of a financial institution. ${ }^{95}$

Kokkinis advocates the introduction of a new statutory provision to hold senior managers personally liable in case an institution fails. Such liability, he claims, should be limited to the total renumeration received during the five years preceding the failure.

In our proposals, outlined below, we go further than Kokkinis.

established elaborate constitutional, parliamentary and judicial provisions to control these functions, to assure that taxes are imposed so far as possible in accordance with the preferences and desires of the public--after all, "taxation without representation" was one of the battle cries of the American Revolution. We have a system of checks and balances to separate the legislative function of imposing taxes and enacting expenditures from the executive function of collecting taxes and administering expenditure programs and from the judicial function of mediating disputes and interpreting the law.

Here the businessman--self-selected or appointed directly or indirectly by stockholders--is to be simultaneously legislator, executive and jurist. He is to decide whom to tax by how much and for what purpose, and he is to spend the proceeds--all this guided only by general exhortations from on high to restrain inflation, improve the environment, fight poverty and so on and on.

The whole justification for permitting the corporate executive to be selected by the stockholders is that the executive is an agent serving the interests of his principal. This justification disappears when the corporate executive imposes taxes and spends the proceeds for "social" purposes. He becomes in effect a public employee, a civil servant, even though he remains in name an employee of a private enterprise."

\footnotetext{
${ }^{94}$ Andreas Kokkinis, ‘Corporate Law and Financial Instability', (London, UK: Routledge), (2018).

${ }^{95}$ Ibid. p. 137.
} 


\section{Calibration}

Our basic proposal is that there should be two separate categories of equity investors for PLCs, 'outside' investors who maintain limited liability, as now, and 'insiders', who should have varying degrees of further liability, as outlined below. But how do you distinguish between these two categories? In principle, the distinction is straightforward. 'Insiders' have access to significantly greater information about the working of the enterprise than 'outsiders', and the potential to use that information to prevent excessively risky actions. In practice, of course, the distinction is not so easy to make. 'Insiders' would include all of the Board of Directors, including the externals. For employees, we would suggest a two-fold categorisation, by status within the company, and by scale of remuneration. Thus any employee on the Executive Board, or who was Chief of a Division would be included. But the key players in a company are frequently indicated by the scale of their remuneration rather than by their formal position. So any employee who was earning a salary in excess of, say, $50 \%$ of that of the CEO, would also be assessed as an 'Insider'. Nevertheless, if the potential sanction of multiple liability arising from failure was regarded as severe, there could be attempts to adjust titles and salaries so as to avoid being categorised as an 'Insider'. So, the regulatory authority should have the right to designate anyone in a particular company as being an 'insider', subject to judicial review. The PRA/FCA under the SM\&CR already requires banks to ensure that all the designated responsibilities are allocated, that these are set out in a "responsibilities map" and that the bank board signs off on this, ensuring no over or underlaps and the appropriateness of the allocations.

Large shareholders are also in a position to access inside information, and to exert influence on the course that a company might follow. So any shareholder with a holding greater than, say, $5 \%$ of the company, should also be regarded as an 'insider'. There is no particular key threshold, above which a large shareholder should be regarded as an 'insider'. In particular institutional shareholders vary in the degree to which they prefer to be active, or passive. It is arguable that one should give shareholders, notably institutional investors, holding between 2 and $5 \%$ of the value of the shares the ability to choose whether to count as an 'outsider', or as an 'insider'. ${ }^{96}$ If they want to count as an 'outsider', they would have to undertake not to exercise voting rights, and not to participate in policy discussions, e.g. at AGMs. They should be allowed to change their preferred designation, but only after a period of notice, say six months.

The base to which the liability should apply would be the remuneration of all those counted as 'insiders', (dividends in the case of large inside shareholders), cumulated from the date that they took on that role. This would apply to all forms of remuneration, except those provided in the form of bailinable debt, with all subsequent transactions in such debt having to be notified. This would apply to the directors and employees.

Not all 'insiders' are equal. In particular, the CEO has much more information and power than any of his subordinates, other members of the Board, or the auditors. One might think that the CEO's liability could be three times the accumulated relevant value of remuneration (ex bail-inables) from the time that he or she had taken up the role of CEO. Board members and chief officers of the company might have two-times liability, and every other 'insider' employee a single liability equal to their accumulated revenue. Similarly, large shareholders with greater than 5\% holdings might have double liability, i.e. for an additional twice par value of their shares, while 'insider' shareholders,

\footnotetext{
${ }^{96}$ In his comments to our paper, Rafael Repullo pointed out the challenges that the growing importance of passive institutional investors presents for our proposal.
} 
between 2 and 5\%, might be liable to pay in an additional par value of their shares, as in the American National Bank system before the 1930s.

That raises two further questions. The first is what should happen when an 'insider' ceases to play that role, e.g. an employee leaves the company, or a large shareholder sells their shares. The second is that an 'insider' may be aware that the company is entering dangerous territory, but cannot persuade management to change direction. In that case, how could they avoid being sanctioned for a policy that they would not themselves advocate?

In the first case, of departure from the role of 'insider', it would seem appropriate to taper the liability according to the degree of 'insider' knowledge and power. Thus, if it was agreed that the CEO should have a three times extra liability, then that liability would decline at a constant rate over the following three years, leaving the CEO with zero further liability exactly three years after they had left. By the same token, those with a two times additional liability, should have it taper at a constant rate until they were free of any further liability after two years; and so on for those with a one-time additional liability.

Then we come to the second issue, which is the question of how those with additional liability can avoid sanction in those cases where they have opposed the policy, but have failed to succeed in changing it. Our suggestion in this case is that those in such a position should address a formal, but confidential and private, letter to the relevant regulators, setting out their concerns about the policy being followed. The regulator would have to formally acknowledge receipt of such letters, and they could then be used in mitigation, or often abandonment of any sanction, should the company then fail. Moreover, in the event of the company failing, for the reasons indicated in such a letter(s), this would in turn act as a form of accountability for the regulators. All such letters would have to be made publicly available in the event of failure. It would be a legal offence for the regulator then not to publish any such letter.

There is a more difficult question, whether the regulator, having received such a private confidential letter of warning, perhaps from the auditor, or an unhappy employee, should make them public. In our view, such warnings need to be investigated further by an independent body, such as the regulator or a financial ombudsman before being made publicly available, since in many cases, they may well be groundless with the maintained policy of the company being appropriate. But if the regulator, after investigation, should feel that the warnings had merit, the first step would then be to have a private discussion with management on the merits of the case, and, if management remained unmoved, the next stage would be to publish the warning (anonymously) together with the regulator's own assessment, at the same time offering management the opportunity to state publicly their own side of the case. When the latter process had been completed, 'outsiders' would then be as well informed as 'insiders' on the merits of the issue.

Note that it puts regulators in the firing line for at least severe reputational damage, if they receive such warnings, fail to act upon them, and the warnings prove prescient.

The purpose of the exercise is to provide appropriate sanctions for failure on those with 'insider' knowledge and power. The particular illustrative numbers chosen in the above section are, obviously, somewhat arbitrary. But the exercise can be calibrated to impose appropriate sanctions for all such 'insiders', whether large shareholders, key employees, or regulators. We think that this would be a better form of governance. 
This approach does not, we believe, leave us open to the Friedman criticism that it completely severs the interests and incentives of the agent (the manager) from that of the principal (the equity holder). The remuneration of both remained totally aligned under our proposal, so long as the company is profitable. It is only in instances of bad outcomes, especially bankruptcies, that the sanction on the managers/insiders becomes more severe than that on the outside equity holders. The aim is to reduce the risk of such bad outcomes being shifted to others, e.g. employees, creditors, taxpayers and, via various externalities, to the economy more widely.

While we would hope, and indeed expect, that greater pecuniary sanctions on inside equity holders, notably managers and CEOs, would significantly reduce excessive risk-taking and bankruptcy, history clearly reveals that unlimited liability did not prevent large scale and systemic occasions of failures. There were major incidences of bank failures, primarily among unlimited liability country banks, in 1825,1837 and $1847,{ }^{97}$ and, of course, it was the failure of the City of Glasgow bank in 1878 with a widespread holding of outsider-type unlimited shareholdings that led to a general transition of banks from unlimited to limited liability. Irrespective of the sanctions involved, most humans are unduly optimistic about their own skills and ability, (it is generally believed that some $90 \%$ of car drivers believe they are in the top 50\% of driving ability). Moreover, systemic failures frequently arise as a result of a general incapacity to assess risk correctly.

Thus it is, perhaps, more common for failure to arise as a result of an invalid appreciation of probabilities, rather than a conscious assumption of additional perceived risk. This, in turn, means that in many cases that there was no intention, mens rea, to put the company, the bank, into a position of excessive risk. Dick Fuld did not think that building up a massive holding of mortgage-backed securities was risky, nor did Fred Goodwin appreciate the risks involved in the ABN-Amro merger. But if in many, perhaps most, cases there was no conscious intention to risk the bank or any moral blame, in the sense of knowingly taking on an exposed position, then there can be no effective basis for a legal sanction. In that sense, the pecuniary sanction that we are proposing is not itself based on any moral, or indeed legal, basis. But note that corporate failures also impact adversely on many stakeholders who are clearly and certainly blameless. What really upset people in the aftermath of the Great Financial Crisis was that many innocent bystanders, homeowners who had their homes respossessed, bank employees, taxpayers, etc., were often seriously damaged, whereas the leading bankers appeared to walk away with their accumulated wealth and forthcoming pension rights entirely unaffected. This was perceived as extremely unfair. One of the main purposes of our proposal is to restore a sense of balance, and fairness, between the sanctions imposed on bankers, as compared with those imposed on other stakeholders; and such a sense of balance needs to be, in some large part, independent of the intentions of the corporate (bank) managers, which intentions in any case would be extremely hard to discern in a court of law.

There might, just possibly, be room for an extension of our proposal. In recent decades, regulatory bodies (as well as the Department of Justice in the USA) have taken to the practice of imposing large fines on corporates when corporate activity is perceived as having been wrongful, for example, the Deepwater disaster for BP, and fines for allowing money laundering and evading sanctions on banks. But such fines primarily fall on outside shareholders, who had no involvement whatsoever in the actions undertaken, and the fines deplete the capital buffers of corporates, often just at the time when they are most needed. What would be desirable, if it could be done, would be to redirect such fines

97 Sir John Clapham, The Bank of England: A History, (Cambridge, UK: Cambridge University Press), (1970). See Volume II, Chapters II, III and IV. 
solely to the segment of inside shareholders, as defined above. It is those who have control over decisions, not the generality of outside shareholders, who should be fined for wrongful activities.

There have been some moves in the general direction that this paper proposes. In particular the adoption of the Senior Management and Certification Regime (SM\&CR) in the UK is a step in the right direction. The SM\&CR, introduced in the UK in December 2013, had several aims. It was seen by the Parliamentary Commission on Banking Standards, as a device that could pierce through what its report repeatedly referred to as an accountability firewall that had hitherto made it hard for senior managers to be held responsible for their failings. Parliament wanted a completely new regime that would ensure "senior managers of banks [would] no longer be able to hide behind an accountability firewall, where they are too distant from the consequences of their responsibilities to be held directly accountable when things go wrong." 98 To regulators, the SM\&CR was seen as a framework that would enhance accountability at the highest level of regulated firms, targeting individuals - as opposed to institutions - and also enable more effective enforcement action. Fundamentally, however, in view of the thesis advanced in this paper, the SM\&CR presents an opportunity to "internalise" the costs of misconduct so that these costs fall on the very individuals involved in reckless behaviour or excessive risk taking, rather than on innocent bystanders (creditors, customer who lose their money, and taxpayers). Furthermore, the SM\&CR could have potential as a deterrent against "externalising" the costs of misconduct to shareholders (where failure results in hefty penalties on the firm) or to taxpayers (when misconduct results in failure that imposes costs on taxpayers).

However, the jury is still out on how effective the SM\&CR has been. This can be explained by a number of factors. First, while the SM\&CR legislation was enacted in December 2013, the framework only initially started in March 2016, and in 2017 it was extended to all financial firms in the UK, a process that has been going on through 2017/18, and has now drifted to the end of 2019. One could rightly argue that there has not been sufficient time to test SM\&CR's efficacy through enforcement and judicial actions, other than few cases such as the whistle blowing case involving the Barclay Bank chief executive. ${ }^{99}$ Second, the framework that is being rolled out today is slightly different in a few but important areas, compared to what the PCBS had recommended in 2013. Notably, the shift from a situation where a senior manager could have been forced to defend against regulatory action by evidencing the actions he or she took to prevent failure, to the current situation where the onus is on regulators, may have partly contributed to the limited enforcement action due to the time it takes to undertake investigations needed to support successful sanctions. Be that as it may, the Press has been full of comments at end 2018 about how low has been the application of fines and other sanctions. Therefore, our contention is that the SMR does not go nearly far enough. It is a start; but our proposal would represent a major extension of the concept that penalties for failure should fall primarily on those with a controlling voice in the corporate decisions taken.

There is also the issue faced by the PRA and FCA of attempting to impose sanctions on senior management based outside the UK. This issue arises due to the way many banking groups operate with key functions and individuals based in other jurisdictions. The legal structure of the bank and its actual operational organisation rarely coincide.

If the pecuniary sanctions imposed on insiders are severe, and the suggestion that CEOs might be made to face unlimited liability would no doubt be seen as severe, then there would surely be attempts

\footnotetext{
${ }^{98}$ Parliamentary Commission on Banking Standards (PCBS), Changing banking for good (HC 175-II, 2013) 489.

${ }^{99}$ Financial Conduct Authority, Final Notice 11 May 2018, (reference JXS02208) para 2.9.
} 
to avoid or evade such sanctions. One of the claims that would be made is that this would significantly reduce the supply of qualified people prepared to take on senior management positions. We very much doubt whether this particular claim has much merit. It is hard to show that during earlier periods when the norm was unlimited liability, there was a shortage of candidates for a senior bank and corporate position. Moreover, the attractions of power, prestige and wealth that attend being a senior manager, in particular a CEO of a major company, will always attract many candidates. Indeed, one might even consider the possibility that an appreciation that failure could lead to penury might even lead to a better class of candidate being prepared to assume corporate leadership.

But there would also be other avoidance measures undertaken, or at least threatened. One such would be to shift the country of incorporation to one where limited liability for all would still remain. That could be prevented, or at least offset, by requiring any organisation with a large-scale operation in the UK to do so in the form of a separately capitalised subsidiary, where the managers of that subsidiary would, in turn, be subject to multiple liability. A second possibility would be to try to avoid such sanctions by taking out insurance, for example, in the form of an extended version of the present Directors and Officers insurance. But we are not particularly concerned about that possibility. It would, for example, be impossible to insure a condition of unlimited liability, and the prospect of multiple liability would lead to the premia needing to be paid for such insurance to become extremely high, and, in turn, would lead the insurance company involved desperate to monitor riskiness, and to withdraw insurance at the first sign of trouble ahead. Finally, those subject to multiple liability could try to avoid the penalty by shifting their wealth to other family members, or to close friends. Again, we would not be overly concerned about this possibility. It would lead to a wider distribution of wealth; and it would put such strain on family and friendship links in the case of failures that the principals involved would only be prepared to shift wealth up to a point. In any case, as noted earlier, we doubt whether managers often have the ability accurately to foresee the probability of their own subsequent failures. So, to conclude, while there would certainly be avoidance measures taken, we do not think that these would be so extensive and successful as to limit or abrogate the purpose and value of the proposal that we make, which would need to be statutorily mandated.

The change-over from unlimited liability to limited liability towards the end of the $19^{\text {th }}$ century was a relatively slow process, taking decades, depending in some large part on experience. While we believe that a generalised shift to a two tier system of equity liability is the ultimate objective to which we should strive, doing so in one huge jump would be impractical. We would have had insufficient prior experience of how such a system would work; the political opposition would be great, even if patently self-interested; the transitional costs would be huge.

So we would want to introduce such a reform on a more gradual basis, starting with the sector where it seems most appropriate. In this respect we would take a leaf out of Peter Conti Brown's proposal. He suggests making SIFIs subject either to much higher capital or to making all shareholders subject to unlimited liability. But the weakness of his proposal is the unfairness, and political unpopularity, of bankrupting innocent, uninformed and powerless outside shareholders. What we would suggest, instead, is to give such SIFIs the alternatives of much higher capital, or adopting a two tier equity system along the lines outlined above. Only the SIFI's CEO might then have unlimited liability, but other insiders would have multiple liability along the lines outlined above. 


\section{Some Extensions}

Additional categories of 'insiders' could be the auditors of the firm, and its Credit Ratings Agencies (even though neither of them are shareholders). In both cases, auditors and CRAs have privileged access to insider information, if they so want, and they provide publicly available information on which investors and counterparties rely. If they take an unduly optimistic view of the prospects of a firm, possibly because they become influenced by the fact that they are remunerated by that firm, then that needs correction and should be subject to sanction. The auditors might have liability equal to twice their accumulated revenue from the failing firm, with the same taper on replacement and ability to warn the regulator privately as already described.

Devising appropriate sanctions for CRAs is considerably more difficult. What they do is to offer an ordinal ranking of credit default risk. The concern is that they may be excessively prone to optimism, because of a bias related to themselves being remunerated by the firm being rated. The ill effect of any such optimism would be seen by the CRA maintaining an excessively high rating, such as AAA, almost up to the very date of default. What one could do is to look at possibly three dates prior to the announcement to default, say two weeks prior, four months prior and one year prior, then if the rating was above $\mathrm{D}$ two weeks prior, or above $\mathrm{B}$ - four months prior and above A- one year prior, then the CRA involved could suffer a sanction. That sanction could be further calibrated to be more severe, the higher above the trigger level the rating at each date remained. The point of the exercise is to try to ensure that CRAs react reasonably promptly to any worsening in their firm's conditions sufficiently far in advance to provide a reasonable warning signal. Admittedly this could cause a hair-trigger problem, with rating agencies rushing to protect themselves against penalties as difficulties become apparent, and thereby worsening confidence. The calibration in this case might be quite complex, but might be feasible. This problem deserves more thought.

A further extension might relate to the imposition of (judicial) fines on companies for bad behaviour. At present the fine is levied on the company as a whole, thereby reducing the residual value of the company, and the market value of all shares. Thus the fine is effectively imposed on all shareholders. But outside shareholders, e.g. in BP for a risky form of drilling in the Gulf of Mexico, and on banks for money laundering, e.g. Danske Bank, had no knowledge whatsoever, nor power to influence the decisions that led to such bad behaviour. So, the innocent are being punished for crimes for which they were guiltless. Furthermore, the fine weakens the capital value of the firm involved, often at just the time when they need a larger buffer to survive under adverse circumstances.

A much better way of proceeding would be to levy such fines only on insider shareholders. Almost by definition, such insiders should have had the information and power to affect the decisions that led up to the bad behaviour. Even in those frequent cases where some insiders did not have the information, the threat of more focussed penalty would make the insiders concerned to enhance risk management and compliance. Admittedly the scale of such fines would have to be lessened, because the available wealth of the insiders is more strictly limited. But the purpose of such fines should never be to provide fiscal support, but rather to deter such bad behaviour in future. The more focussed the fines are on those insiders with power and information, the more likely it is that those fines will have the desired effect. 


\section{Conclusion}

There are many classes of debt, with various degrees of seniority. The purpose of this paper is to suggest that, similarly, there should be two classes of equity. The division should be between outsiders with no inside knowledge of the working of the firm, and/or ability to control its decisions, and insiders who have both the information and capacity to influence corporate decision-making. On the upside, when the bank/company is profitable, the interests of the insiders and outsiders would remain exactly aligned with each other, as at present. But limited liability applied generally leads to moral hazard and an excessive tendency to take risks, since bad outcomes can lead to costs being shifted to blameless outsiders and other stakeholders. The purpose of this proposal would be to shift the costs of failure back towards those who have the responsibility for taking these decisions. Whether, or not, the failure was due to consciously excessive risk-taking, or other moral failings, failures will have serious costs and consequences. These need to be shared more fairly amongst those responsible for such decisions, alongside other stakeholders who get adversely affected by such outcomes.

A further concluding observation relates to the potential interaction between extended liability for managers/insiders and regulation. The more that managers/insiders are required to take on additional liability, the less intrusive and extensive the regulation would need to be, given the internalisation of costs that such extended liability would entail. In particular, firms like C. Hoare \& Co., who voluntarily choose to adopt unlimited liability should have the intensity of supervision and regulation greatly lessened. 